\title{
A literatura infantil e juvenil brasileira contemporânea e a desobediência epistêmica: reflexões e impasses
}

\author{
La literatura infantil y juvenil brasileña contemporánea y la \\ desobediencia epistémica: reflexiones y bloqueos
}

TELMA SILVA

\section{Resumo}

Este trabalho visa realizar uma reflexão sobre a literatura infantil e juvenil produzida no Brasil após a Lei 10.639/2003, explicitando em que medida ela vai ou não ao encontro do que é postulado pelo documento legal. Para tanto, valho-me das noções de "política de identidade" e de "identidade em política", pensadas por Walter Mignolo, quando discute o que é "desobediência epistêmica". Faço um diálogo com Michel Foucault, a partir de sua reflexão sobre episteme e com base no prefácio de As palavras e as coisas. A concepção de estereótipo e seus usos na literatura brasileira, conforme apresentado em Bastide, Brookshow e Proença Filho, contribui para uma incursão na história da literatura infantil e juvenil brasileira, que dividi em 5 fases, para evidenciar sua relação direta com as temáticas produzidas pela literatura brasileira dita para os adultos, destacando os estereótipos produzidos para tipificar os negros e cristalizando uma visão monotópica dessas personagens. Como contraponto a essa discussão, apresentei uma breve análise do livro O tronco do Ipé, de José de Alencar, no qual esses estereótipos se manifestam com bastante clareza. Destaquei algumas produções literárias da quinta fase para demonstrar em que medida elas avançam desconstruindo esses estereótipos, assinalando para conhecimentos pluriversais ou permanecem no sistema universal da episteme ocidental. No primeiro grupo, há aqueles livros que conservam o substrato cultural eurocêntrico, fazendo alguns ajustes para reacomodar personagens e espaços, dando uma nova coloração ao mito da democracia racial. No segundo, destaquei de que modo as produções baseadas em estudos sobre as culturas africanas, que fundamentam a afro-brasileira, apontam na direção da pluralidade praticando, portanto, a desobediência epistêmica.

Palavras-chave: Literatura infantil e juvenil brasileira. Desobediência epistêmica. Estereótipo. Lei $10.639 / 2003$.

\footnotetext{
a Universidade Federal de Minas Gerais (UFMG), Belo Horizonte, MG, Brasil. Doutora em Letras, e-mail: tbs2019@fae.ufmg.br
} 


\section{Resumén}

Este trabajo quiere realizar una reflexión sobre la literatura infantil y juvenil producida en Brasil después de la Ley 10.639/2003, explicitando en que medida va o no en contra de lo que es postulado por el documento legal. Para ello, me valgo de las nociones de "política de identidad", pensadas por Walter Mignolo cuando discute lo que es "desobediencia epistémica". Hago un diálogo con Michel Foucault, a partir de su reflexión sobre episteme y con base en el prefacio de Las palabras y las cosas. La concepción de estereotipo y sus usos en la literatura brasileña, según presentado en Bastide, Brookshow y Proença Filho, contribuye para una incursión en la historia de la literatura infantil y juvenil brasileña, a la cual dividí en 5 fases, para evidenciar su relación directa con las temáticas producidas por la literatura brasileña dictada para los adultos, destacando los estereotipos producidos para tipificar los negros, cristalizando una visión mono tópica de esos personajes. Como contrapunto para esa discusión, presenté breve análisis del libro O tronco do Ipé, de José de Alencar, en lo cual esos estereotipos se manifiestan con bastante claridad. Destaqué algunas producciones literarias de quinta fase para demonstrar en qué medida ellas avanzan des construyendo esos estereotipos y señalando para conocimientos pluriversales o permanecen en el sistema universal de la episteme occidental. En el primer grupo, hay aquellos libros que conservan el substrato cultural eurocéntrico, haciendo algunos ajustes para reacomodar personajes y espacios, dando una nueva coloración al mito de la democracia racial. En el segundo, destaqué de qué modo las producciones basadas en estudios sobre las culturas africanas que fundamentan la afrobrasileña apuntan en la dirección de la pluralidad practicando, por lo tanto, la desobediencia epistémica.

Palabras clave: Literatura infantil y juvenil brasileña. Desobediencia epistémica. estereotipo. Ley 10.639/2003.

\section{Introdução}

No artigo "Desobediência epistêmica: a opção descolonial e o significado de identidade em política", Walter Mignolo contrapõe os termos "política de identidade" e "identidade em política" argumentando ser o primeiro

[...] todo o espectro das identidades sociais [...] com a aparência natural do mundo. Ou seja, ser branco, heterossexual e do sexo masculino são as principais características de uma política de identidade que denota identidades tanto similares quanto opostas como essencialistas e fundamentalistas (MIGNOLO, 2008, p. 289).

A identidade em política seria uma "[...] opção descolonial” forjada com "a construção de teorias e [...] organização de ações políticas fundamentadas em identidades que foram alocadas [...] por discursos imperiais [...]" (MIGNOLO, 2008, p. 289). Antes de avançar com a discussão, apresento a noção ocidental de espitesme, a qual é considerada um tipo de saber diferente de opinião $($ doxa) ou senso comum, porque dotado de "garantias incontroversas de validade". Michel Foucault em As palavras e as coisas, segundo Abbagnano, adota o termo para "aludir ao conjunto de grades conceituais, inconscientes e anônimas que compõem a base dos conhecimentos (e das 
práticas) de certa época [...]” (ABBAGNANO, 2012, p. 391). O termo é abordado por Foucault numa perspectiva plural e histórica, pois não é invariante, como defendiam Kant e Lévi-Strauss, já que suas "condições duram apenas um período limitado de tempo" (ABBAGNANO, 2012, p. 391). As mudanças epistêmicas ocorrem através de uma série de "descontinuidades enigmáticas, deixando de repente de ser percebidas, enunciadas e sabidas” (ABBAGNANO, 2012, p. 391). Para o pensador francês, "ao caráter contingente das relações interepistêmicas corresponde o caráter necessário das relações subepistêmicas, ou seja, entre a E. geral e saberes particulares de uma época (ABBAGNANO, 2012, p. 391).

Esse recuo à episteme ocidental permite demonstrar não só o ponto de partida de Walter Mignolo, que faz a crítica ao saber eurocentrado, formulado pelo que ele chama de línguas imperiais da modernidade: inglês, francês, espanhol, alemão, português e italiano, mas também em que medida o pensamento foucaultiano questiona internamente o conhecimento com o qual se posiciona discursivamente. O eurocentrismo emerge de uma forma de pensar veiculada por essas línguas fundamentadas no grego e no latim. A colonialidade é, por sua vez, a grande invenção da modernidade, produtora de conceitos universais, "como ciência, filosofia, Cristianismo, liberalismo, Marxismo [...]”. Essa perspectiva universal, que Mignolo denomina política de identidade, "não se manifesta como tal, mas através de conceitos universais abstratos" (MIGNOLO, 2008, p. 289).

Ao tratar a episteme como pluralidade histórica, Foucault evidencia, principalmente a partir do século XIX, que "o campo epistemológico se fragmenta ou, antes, explode em direções diferentes", não se ordenando "conforme o ideal de uma matematização perfeita", se desenrolando num espaço volumoso e aberto (FOUCAULT, 2002, p. 478). As palavras e as coisas, livro de 1966, inicia um percurso de afastamento desse saber universal, pré-discursivo, em direção a uma episteme do Sul. Nele, Foucault tributa a Borges a origem do opúsculo:

Este livro nasceu de um texto de Borges. Do riso que, com sua leitura, perturba todas as familiaridades do
pensamento - do nosso: daquele que tem nossa idade e nossa geografia -, abalando todas as superfícies
ordenadas e todos os planos que tornam sensata para nós a profusão dos seres, fazendo vacilar e inquietando,
por muito tempo, nossa prática milenar do Mesmo e do Outro (FOUCAULT, 2002, p. IX).

O texto do escritor argentino Jorge Luis Borges cita certa enciclopédia chinesa que divide os animais em taxes improváveis, como os embalsamados, os fabulosos, os cães em liberdade, os etecetera. Esse jogo literário que Foucault considera "como encanto exótico de um outro pensamento, é o limite do nosso: a impossibilidade patente de pensar nisso" (FOUCAULT, 2002, 
p. IX). O autor destaca a peripécia do escritor argentino em transgredir, não pela aproximação entre animais reais e fabulosos, mas pela ligação que estabelece entre eles com a série alfabética; pela "enumeração que a [...] faz entrechocar-se" (FOUCAULT, 2002, p. X), arruinando a possibilidade dos encontros, dada a improbabilidade, ou mesmo o contrassenso de se avizinharem a não ser no não-lugar da linguagem literária. Foucault chama a atenção ainda para "[a] categoria central dos animais 'incluídos na presente classificação" (FOUCAULT, 2002, p. $\mathrm{XI}$ ), evidenciando a paradoxal contradição de um conjunto classificatório qualquer conseguir uma relação estável entre conteúdo e continente, alojando a todos numa só categoria (FOUCAULT, 2002).

Essa digressão ao texto de Foucault é para tratar do que Walter Mignolo definiu como “identidade em política". O espanto do autor francês me parece residir na descoberta da impossibilidade de uma episteme universal, pois o Outro pensou o impensado pela episteme eurocêntrica, perturbando as "familiaridades do pensamento". A identidade em política, portanto, seria resultado dessa desobediência epistêmica desalojadora de uma categoria de pensamento universalizante e singular, para se pensar em categorias pluriversais. Para Mignolo,

[u]ma das realizações da razão imperial foi a de afirmar-se como uma identidade superior ao construir construtos inferiores (raciais, nacionais, religiosos, sexuais, de gênero), e de expeli-los para fora da esfera normativa do "real". [...] É da exterioridade, das exterioridades pluriversais que circundam a modernidade imperial ocidental (quer dizer, grego, latino, etc.), que as opções descoloniais se reposicionaram e emergiram com força (MIGNOLO, 2008, p. 291).

Compreendo que a desobediência epistêmica é uma opção decolonial que afirma a existência de uma outra América Latina, para além da invenção colonial. Essas considerações me servirão para pensar a (in)visibilidade das personagens negras na literatura infantil brasileira e em que medida sua participação nos processos fabulatórios do país contribuem para a constituição de um "lugar de fala" na literatura produzida para crianças antes e depois da Lei 10.639/2003, que altera a LDBEN/9394/96, para incluir a história e a cultura dos povos africanos e afrobrasileiros, ou seja, outras epistemes. Para tanto, associarei à noção de política de identidade o conceito de estereótipo, com o qual farei um breve percurso pela história da literatura infantil no Brasil passando, antes, por José de Alencar, com quem argumento para demonstrar de que maneira a agenda temática da literatura brasileira pautará as questões da literatura infantil, por razões que me parecem claras: os autores que escreviam a literatura "adulta" foram os mesmos a 
escreverem para as crianças no nascedouro da literatura infantil, como Júlia Lopes de Almeida, Olavo Bilac, Coelho Neto, Manuel Bonfim.

\section{Literatura infantil brasileira em perspectiva}

O estereótipo é a causa e o efeito do pré-julgamento de um indivíduo por seu pertencimento étnico. É a base ideológica de dominação do negro pelo branco (BASTIDE, 1972; BROOKSHAW, 1983; PROENÇA FILHO, 2004). Os estudos de Roger Bastide, de David Brookshow e de Domício Proença Filho, no campo da literatura, realizam uma espécie de senso da participação do negro na literatura brasileira, do século 17 ao 20. Os resultados a que chegaram demonstram que a literatura brasileira, ao se ancorar em estereótipos para composição de personagens negras, dá visibilidade ao que o homem branco produziu sobre eles numa perspectiva universalizante, invisibilizando suas histórias e singularidades. Esses estereótipos ganham mais visibilidade ainda no romantismo brasileiro, momento no qual um ideal de nação, para consolidar os valores da pátria independente, estava sendo forjado.

Quero exemplificar essa estereotipização com algumas personagens em $O$ tronco do ipê, de José de Alencar. De acordo com Zildete Lopes de Souza, Alencar entendia a literatura como espaço eficaz de expressão da pátria:

É nela que o povo deveria reconhecer-se como nação, deveria conhecer sua geografia, seus costumes, sua cultura, antes ignorada em função da imposição da cultura do colonizador. Enfim, é pela literatura, pela emancipação linguística, que a nação poderia encontrar e registrar uma identidade, construir uma autoimagem. Com esse propósito, Alencar não só buscou forjar uma mitologia, através dos romances indianistas, que sustentasse o surgimento da nação, como procurou, através dos romances urbanos e regionalistas, oferecer um painel amplo e diversificado do Brasil, descrevendo lugares, cenas, fatos e costumes do país (SOUZA, 2015, p. 98).

Há, no romance em questão, o empenho de criar uma consciência identitária coletiva. E é nesse esforço de composição do "todos como um”, como diria Benedict Anderson, que o negro, elaborado estereotipicamente por Alencar, emerge como o menos um do todo.

De modo mais amplo, o romance comunga da ideia de que no Brasil a escravidão foi benevolente, pois a relação entre senhores e escravos é de respeito mútuo e próxima, baseada na afetividade, principalmente entre os negros que faziam, por vezes, o papel designado aos pais, como se lê no excerto a seguir, no qual Mário, o herói da trama, reencontra o preto velho que cuidara dele quando lhe faltara o pai: "Mário cingiu-lhe o pescoço com os braços e beijou-lhe as 
cãs. O Negro apertando-o ao peito, soluçava como uma criança. Ali ficaram absorvidos na ardente expansão dos sentimentos que lhes tumultuavam no seio" (ALENCAR, 1958, p. 680). Há, como se vê, o claro objetivo de expressar o laço de familiaridade entre senhores e escravizados. Para Lopes, José de Alencar

[...] encontra na relação de afeto estabelecida entre os membros da classe senhorial e os escravos o ingrediente necessário para atenuar as diferenças raciais e culturais e dar corpo e sentido a uma nação confraternizada, que convive harmoniosamente com a diferença (SOUZA, 2015, p. 121).

O autor cearense não toca no trabalho do eito; prefere dar visibilidade à lida na cozinha da casa-grande, um ambiente aparentemente menos opressor, lugar cujo "ruído produzido pelos diferentes serviços se compunha também pela garrulice inesgotável das raparigas que falavam todas ao mesmo tempo" (ALENCAR, 1958, p. 720). Ali, “[...] as escravas realizam os trabalhos enquanto conversam, cochilam, trocam expectativas e impressões sobre assuntos variados, com participação e aprovação da senhora” (SOUZA, 2015, p. 125).

Transitam pela narrativa negros que encarnam o estereótipo da feiura; é caso de Pai Benedito, que também é visto por algumas senhoras que frequentavam a fazenda como agente do mal, pois lidava com forças ocultas. Desfilam por ali personagens como Eufrosina, a mucama que encarna a dupla condição: é escravizada, mas conta com certos "privilégios” por ser objeto de estimação da baronesa. Martinho é a expressão da subserviência, enquanto Florência, por não ser escrava doméstica, está, por oposição a Eufrosina, no outro extremo da relação com os senhores; faz parte da ralé da enxada.

$\mathrm{O}$ autor entroniza nessas personagens comportamentos que vêm se instituindo na literatura brasileira desde seus primórdios, como mostram os estudos de Bastide, além de atribuir a elas juízos de valor quanto a um tipo de trabalho escravo mais suave ou mais áspero, fazendo os trabalhadores da casa se sentirem em posição superior àqueles que trabalhavam nas plantações. Conforme Souza, "Florência e Amâncio, assim como Martinho, Felícia e Eufrosina, mostram-se conformados com sua condição de cativos, como se para eles a [...] posição de maior prestígio que pudessem almejar fosse o trabalho como mucama ou pajem e não a liberdade e a inserção na sociedade" (SOUZA, 2015, p. 129), evidenciando pelo menos mais dois estereótipos: a resignação e a subserviência.

A literatura infantil brasileira, por sua vez, tem uma história cujo início se confunde com o nascimento da república e se nutre dos paradigmas da literatura brasileira de então, dentre os 
quais estão os valores pátrios. Nascendo para contribuir na educação das crianças de famílias burguesas, está ancorada ao projeto de modernização que vai se consolidando no período pós abolição (LAJOLO; ZILBERMAN, 1993). Nessa primeira fase, em que os autores são os mesmos que escrevem a literatura brasileira, assiste-se à incorporação dos estereótipos negativos que já haviam se tornado norma em nossa literatura. Olavo Bilac, no conto "Mãe Maria”, deixa clara a relação genealógica da nascente literatura infantil com a já consolidada literatura nacional. Leiamos alguns fragmentos da breve narrativa:

Conosco, a sua vida foi quase feliz. Na cidade, o cativeiro era infinitamente mais brando que na roça. Aqui, se havia menos trabalho sem tréguas, não havia, ao menos, o chicote do feitor. Lá fora, sim! Lá fora, era a labuta estafante do café, os dias terríveis sob o sol implacável, a comida pouca e o castigo muito.

$[\ldots]$

Quando o primeiro semestre findou, já mãe Maria, e sua face, e sua carapinha, e as suas mãos, e a sua voz, e as suas histórias, me apareciam indistintamente, como no fundo de um passado remoto.

[...]

Um ano de colégio bastara para me transformar. E, agora, eu aparecia à velha ama-seca, como um novo sinhômoço, - um sinhô-moço que tinha onze anos, que já sabia ler e escrever, que já se julgava um homem, e que às histórias atrapalhadas e tolas de mãe Maria preferia a malha e a ginástica (BILAC, 1961, s. p.).

Há aqui a ideia de uma escravidão benevolente, quase um favor a quem é escravizado, posição semelhante à de Alencar, e ainda uma forma característica de tratar o aspecto físico dos negros. Mãe Maria não tem cabelo, tem carapinha, termo assim dicionarizado: “1. cabelo semelhante à lã, muito crespo e denso, próprio da gente de raça negra; cabelo agastado, carrapicho, lã, pixaim” (HOUAISS, VILLAR, 2009, p. 401). Outro destaque é para a oposição entre o saber escolar e o saber oral da velha, que passa a ser visto como "histórias atrapalhadas e tolas", fazendo lembrar o que aparecerá na fase seguinte, com Monteiro Lobato. Em Histórias da Tia Nastácia, Emília se posiciona sobre os casos da preta:

- Pois cá comigo - disse Emília - só aturo essas histórias como estudos da ignorância e burrice do povo. Prazer não sinto nenhum. Não são engraçadas, não tem humorismo. Parecem-me muito grosseiras e bárbaras - coisa mesmo de negra beiçuda, como tia Nastácia. Não gosto, não gosto e não gosto... (LOBATO, 1934, p. 19).

De modo geral, nessa fase, que corresponde aos anos 1920-1945, a produção literária tem como característica a intencionalidade pedagógica, resultando num inexpressivo nível literário, devido ao predomínio do imediatismo das informações (COELHO, 1991). Monteiro Lobato, claro, é exceção a essa regra, não só pelas obras clássicas traduzidas ou adaptadas, mas por seu papel como o criador de uma literatura verdadeiramente voltada aos interesses das crianças. O escritor, porém, não se furtou a introduzir nessa literatura estereótipos desfavoráveis aos negros. No referido livro, a despeito de parecer protagonismo intitular o volume com o nome da 
personagem, o que vejo é o silenciamento de sua voz através das opiniões eurocêntricas da boneca Emília, em favor da literatura de Lewis Carrol, Oscar Wilde, em detrimento dos casos populares contados pela cozinheira do Sítio do Picapau Amarelo, que é descrita tanto verbal quanto visualmente como uma negra beiçuda, nariz achatado em demasia, os pés grosseiros; é analfabeta e quase sempre se horroriza com o conhecimento científico do Visconde.

No terceiro momento, também conhecido como era pós-lobatiana, assistimos à permanência dos estereótipos da fase anterior. A bonequinha preta (1938), de Alaíde Lisboa, na transição entre a segunda e a terceira fases, é considerado hoje um clássico, já em sua $22^{a}$ edição e com mais de um milhão de cópias vendidas. Essa informação nos dá uma ideia de como o livro foi bem acolhido pelos leitores, ainda que nele a boneca preta, que ganha vida e experimenta sair de casa, desobedecendo às ordens de sua dona, esteja na condição de objeto, pois é propriedade de uma menina branca. Com frases simples e ordenadas parataticamente, a narrativa é bastante direta: "Mariazinha tem uma boneca. A boneca de Mariazinha é preta como carvão. A boneca de Mariazinha é muito bonita! Ela tem duas trancinhas, tem a boca vermelha e os olhos bem redondos. Mariazinha gosta tanto da Bonequinha Preta! (LISBOA, 2004, p. 5). Ao ser descrita, a boneca recebe o qualificador "preta", adjetivo que vem acompanhado de um reforço dado pelo símile: "é preta como carvão". Não basta ser preta, é necessário que a narradora intensifique a cor da boneca, de modo que, ao ser caracterizada como "muito bonita", a expressão perca em força adjetivacional, pois o atributo preta se espalha pela narrativa com 30 aparições em 39 páginas, com 18 delas destinadas à ilustração. Nas páginas onde o texto aparece, geralmente ocupa menos de metade do espaço; o restante é composto pelas imagens. No último período da citação acima, "Bonequinha Preta" vira nome próprio devido às iniciais maiúsculas com que passa a ser grafado até o final da narrativa (Está clara a condição da boneca como contraparte da boneca de pano do Sítio do Picapau Amarelo). O vocábulo "preta”, como adjetivo, aparece uma única vez na narrativa, passando na segunda entrada a ser substantivo próprio, mas, semanticamente, é como adjetivo que ele vai produzir sentidos. A leitura do livro, seja feita pelo adulto para criança ou por ela própria, está ancorada num imaginário escravocrata, em que o negro é propriedade do branco. Na narrativa, a diferença é que a boneca fujona não receberá uma punição, como historicamente acontecia aos negros que tentavam escapar da escravidão. Mas há ali, subjacente, uma repreensão; do contrário, não haveria razão para os seguintes dizeres quase ao final do texto: "Mariazinha não se zanga com a Bonequinha Preta. A bonequinha promete não desobedecer 
mais" (LISBOA, 2004, p. 37). Ora, se não há zanga, por qual razão a boneca teria que prometer obediência? Diferente da boneca do Sítio, que ganha vida, vontade própria e manifesta opiniões polêmicas, a personagem de Lisboa ganha vida, foge, mas não tem voz ativa na história, a despeito de dar título ao livro, como Tia Nastácia. Emília, por sua vez, é uma boneca que mora no sítio e, a partir do momento em que deixa de ser objeto para ser sujeito, se torna dona do próprio nariz. Já a Bonequinha Preta deve resignar-se à condição de objeto de estima de sua dona, como Eufrosina em $O$ tronco do ipê, apresentado acima.

Há um detalhe curioso sobre Bonequinha preta e, especificamente, sobre o fragmento inicial destacado. Até a segunda edição, o segundo período da introdução da narrativa era assim: "Mas a boneca de Mariazinha é muito bonita!" (LISBOA, 1938, p. 7, grifo meu). A partir da terceira edição, houve uma reorganização frasal e a conjunção adversativa "mas" foi apagada. Sintaticamente a questão parece ter sido resolvida; semanticamente, entretanto, o "mas" continua lá fazendo-nos lembrar que, apesar de preta como carvão, é bonita. Como se a beleza vista nela fosse uma concessão, porque as negras não o podem ser verdadeiramente tendo elas uma morfologia tão distinta das brancas.

A quarta fase da literatura infantil brasileira foi marcada pela problematização dos estereótipos. Entre os anos 60/70 do século 20, a produção literária para crianças passa por um processo de profissionalização com a criação de instituições ligadas à promoção da leitura e da literatura infantil, como a Fundação Nacional do Livro Infantil e Juvenil (1968); o Centro de Estudos da Literatura Infantil e Juvenil (1973); a Academia Brasileira de Literatura Infantil e Juvenil (1979) e Associações de professores de língua e literatura. Há ainda traços fortes da herança lobatiana, porém outras tendências marcam esse momento com a representação realista do contexto social: conflitos familiares e existenciais, vida urbana, miséria, marginalidade e preconceito racial. Nesse período vão despontar muitos autores que tratam de questões étnicoraciais em suas produções, dentre os quais estão Ziraldo, Ana Maria Machado, Rogério Andrade Barbosa, Júlio Emílio Braz e outros.

Quero destacar dessa fase uma publicação de Ana Maria Machado. Em 1986 vem a público o livro Menina bonita do laço de fita, com garantido sucesso de público. Nele, temos uma menina negra como protagonista e um coelho com imensa vontade de ter a mesma cor que ela. A garota, talvez por desconhecer as razões de sua cor, apresenta várias justificativas que serão experimentadas pelo coelho, sem sucesso, até ele conhecer uma coelhinha preta, por quem se 
apaixona e com quem tem vários filhotes. Conforme diz a narradora, "[t]inha coelho pra todo gosto: branco bem branco, branco meio cinza, branco malhado de preto, preto malhado de branco e até uma coelha bem pretinha. Já se sabe, afilhada da tal menina bonita que morava na casa ao lado" (MACHADO, 2011, p. 21). Claro que essa diversidade de tons de pele metaforiza o Brasil e seu complexo histórico racial, principalmente marcado, a partir dos anos 30 do século 20, pela ideia de democracia racial. No livro, o tom branco de pele é o que predomina no processo de miscigenação; a coelha preta é a última componente nessa paleta de cores e, sintática e semanticamente, sua entrada no texto é antecedida pelo advérbio de inclusão "até", que soa como uma concessão, expressando o limite da tolerância em relação à presença do negro nessa composição racial. O adjetivo "pretinha", no diminutivo, é antecedido pelo advérbio de intensidade "bem". Enquanto o diminutivo atenua a carga do adjetivo, o advérbio a intensifica. Pensando no senso comum, esse uso estratégico de "bem” lembra, em situações de fala, quando há necessidade de se reforçar o sentido de alguma coisa, para que seja devidamente imaginada pelo interlocutor.

Alinhado com o texto verbal, o texto visual, em página dupla (p. 20-21), apresenta 13 coelhos de várias cores, estando à esquerda o pai branco, à direita a mãe preta; entre eles 11 coelhos de diversas cores, mas a filhote preta só aparece adiante, com ilustração em página dupla, puxando um carrinho de bebê com uma bonequinha preta. O excerto final: "E quando a coelhinha saía, de laço colorido no pescoço, sempre encontrava alguém que perguntava: - Coelha bonita do laço de fita, qual é teu segredo pra ser tão pretinha? E ela respondia: - conselhos da mãe da minha madrinha [...]" (MACHADO, 2011, p. 22), dialoga com um episódio descrito nas páginas 14 e 15, quando o coelho, em mais uma tentativa, vai à casa da menina à procura do segredo para ser tão pretinha e a mãe intervém com a intenção de ensinar à menina sobre sua ancestralidade. Dois aspectos chamam a atenção nesse momento da narrativa: a mãe, "uma mulata linda e risonha”, e o que ela diz: “- Artes de uma avó preta que ela tinha [...]” (MACHADO, 2011, p. 15). Na ilustração, o coelho abre um sorriso que traduz ter compreendido o que precisava ser feito, e que será confirmado nas páginas 20 e 21 . A mãe e a filha, numa poltrona, seguram um livro. Na mão esquerda, a mãe sustenta um porta-retratos com a fotografia da avó. Se, por um lado, assiste-se à celebração de diferença e o leitor é convidado a pensar em uma ideia de ancestralidade, que ainda não era discutida no Brasil dos anos 80, por outro, uma visão estereotipada da mulher — mulata linda e risonha — convive com essa posição progressista 
de conhecer e valorizar as origens. Observem que a discussão aqui e no livro de Lisboa está girando em torno da adjetivação porque é nela que depreendemos as jogadas discursivas que não debelam o estereótipo, apenas o suavizam, sem resolver a questão.

Para Roger Bastide, a apologia à beleza da mulata reforça muito mais a glorificação da cor branca, tendo em vista que a beleza da mulata só é possível porque está mais próxima do padrão europeu. O caso em questão nos faz lembrar o estereótipo da mulata sensual, lasciva, imoral e de riso fácil que povoou a literatura brasileira principalmente a partir da segunda metade do século XIX. Não que aqui o trato seja depreciativo - convém lembrar que os estereótipos são ambivalentes —, mas permanece na ordem dos nossos discursos uma prática resistente, mesmo que estejamos a defender posições contrárias ao preconceito racial, como acredito ser o caso das duas autoras apresentadas. Não há como negar, contudo, que são livros infantis, aclamados pelo público, e que expressam, num intervalo de 48 anos, a constância de um discurso racista porque, como diz Lilia Schawarcz, no Brasil, o racismo é uma linguagem e, como tal, está entranhado e naturalizado em nossas práticas.

A quinta fase dessa literatura é aquela que se reconfigura, em parte, devido à lei 10.639/2003, quando identifico não só o combate mais exacerbado desses estereótipos, mas também sua reversão em algo efetivamente positivo. Claro que há, ainda, produções literárias que insistem na manutenção dos estereótipos negativos ou apenas suavizam-no com uma produção que adapta os clássicos da literatura infantil ocidental fazendo alguns ajustes espaciais, de costumes, colorindo personagens, que passam a ser negras, mas o substrato formal e do pensamento continua sendo aquele eurocentrado. Antes de entrar nessa discussão, creio ser importante fazer um breve recuo para destacar a força dos movimentos sociais ao longo do século XX, que foram fundamentais para a materialização de suas reivindicações em outras formações discursivas, como a lei mencionada. A questão é saber como ela tem se consubstanciado na prática.

\section{A literatura infantil pós lei 10.639/2003}

Os movimentos negros no Brasil, oriundos de frentes distintas, num processo similar aos movimentos dessa natureza pelo mundo, visam a desconstrução, de modo mais amplo, dos estereótipos negativos forjados no sistema de pensamento ocidental e atribuídos aos negros. 
Entre os anos 40 e 50 emerge uma preocupação crescente com a cultura e com a identidade negras no país. Desde o Teatro Experimental do Negro (1945), passando pelo Primeiro Congresso Negro Brasileiro (1950), pelo reconhecimento de nossas raízes africanas nas décadas de 70/80, pela exaltação das origens e divulgação das tradições, pela crítica ao colonialismo e à visão ufanista da abolição da escravidão, o que se vê é um ideário em torno do que chamo de “identidade em política”. A força e a resiliência desses movimentos vão desembocar na referida lei, deixando evidente que não foi uma produção espontânea, mas fruto de uma história mal contada, precisando, entretanto, ser recontada no intuito de descontruir o mito da democracia racial que modelou a forma de se contar a história do Brasil.

Gostaria de destacar aqui a reação do Mercado Editorial, especificamente no campo da literatura infantil, que percebe o vazio produzido pela nova legislação, e reage de modo expressivo colocando em circulação não apenas a "nova" produção brasileira, mas também a internacional. A questão que passo a discutir a partir daqui é em que medida esta que estou denominando quinta fase da literatura infantil e juvenil dá continuidade ao perfil da literatura produzida até então, reforçando os estereótipos negativos sobre o negro ou produzindo uma discursividade na qual se pode compreender o que Mignolo chama de "identidade em política". Ou seja, essa literatura reacomoda o mito da democracia racial ou produz uma exterioridade explicitando questões até então silenciadas pelo discurso oficialmente constituído? Quero desenvolver a parte final deste texto em dois momentos. O primeiro é para dizer em que medida essa literatura pós-lei 10.639 manteve e tem mantido a tradição do estereótipo, cristalizada nas fases anteriores, se situando, portanto, no plano da política de identidade. No segundo, apresento algumas alternativas cuja proposta é não somente a desconstrução, mas também a superação da tradição do estereótipo, se aproximando da identidade em política.

Está claro para mim que as culturas comunicam e que aprendemos a partir de e com outros sistemas de pensamento. Com a literatura não é diferente e os diálogos entre culturas são salutares para a compreensão da nossa humanidade, das nossas diferenças. Os textos são produtos da cultura, do encontro e do confronto entre elas e por isso considerados por Mikhail Bakhtin como dialógicos, com origem em várias fontes. A literatura, seja ela oral ou escrita, é patrimônio da humanidade e, como tal, infunde outras produções em tempos e espaços distintos. É bastante comum, portanto, que uma história sirva de inspiração a outras e produza uma semiose ilimitada. A história de Chapeuzinho Vermelho, por exemplo, passou por sucessivas 
transformações motivadas pela dinâmica de valores culturais e ideológicos. O conto remonta ao século X e era contado em diferentes países europeus, como França, Itália e Alemanha. A primeira versão impressa é de Charles Perrault, no final do século XVII. Os irmãos Grimm, no século XIX, também publicam sua versão já com algumas alterações e, de lá para cá, centenas de versões foram criadas. No Brasil, a mais recente de que tenho notícia foi a lançada pela Mazza Edições: Chapeuz̧inho Vermelho e o Boto-cor-de-rosa (2020), com adaptação de Cristina Agostinho e Ronaldo Simões Coelho, com ilustrações de Walter Lara. O relato está ambientado na floresta amazônica, o lobo foi substituído pelo boto-cor-de rosa e a protagonista é uma menina negra. Num artigo de opinião de Luana Tolentino, publicado na revista Carta Capital, em 17 de abril de 2020, a autora diz que o projeto editorial da Mazza, de reler clássicos da literatura infantil tradicional, vai na contramão do “processo de invisibilidade e violência racial” brasileiro. Para ela,

[n]ão basta que os livros infantis tenham crianças negras em suas páginas. É necessário que as imagens e as histórias estejam alinhadas com a construção de identidades positivas, como também com a afirmação de referenciais de beleza que contemplem a pluralidade étnicoracial existente no país (TOLENTINO, 2020, s. p.).

Concordo com o posicionamento da autora e acredito no poder das experiências simbólicas promovidas pela literatura e que, nesse sentido, a produção após a lei tem buscado reconfigurar a literatura para que personagens negras protagonizem relatos. Porém, discordo da forma como esses projetos estão generalizados por várias editoras que têm se empenhado na reelaboração de clássicos da literatura infantil e juvenil de origem europeia, por me parecer que há aí mais uma remodelação do ponto de vista da composição: muda-se o cenário, troca-se o vilão, a protagonista que, no caso em questão, "além de linda [...] é esperta e generosa", mantendo-se o substrato cultural de origem europeia. Não que não se possa fazê-lo; não creio, porém, que projetos dessa natureza consigam avançar no sentido de desconstruir o mito da democracia racial, que vem, ainda hoje, nos obrigando a contar uma história única. A lei não determina que sejam incluídas as culturas africanas e afro-brasileiras na educação brasileira? Se a literatura, como tecnologia, é capaz de contribuir, no campo do simbólico, para desconstrução de estereótipos, porque foi capaz de criá-los, nesse caso parece reforçar a falta de base cultural para fundamentar experiências literárias que dialoguem com conhecimentos que tiveram no continente africano sua suposta origem. 
Acontece o mesmo com Opequeno Polegar (2018), adaptado e ilustrado pelos autores acima mencionados e constante no catálogo da mesma editora. Nessa narrativa, o leitor é levado para o cenário paradisíaco da Serra da Capivara onde, em certo momento, o protagonista se deleita com as inscrições rupestres. Sem dúvida, a qualidade das imagens é primorosa, assim como a do livro anterior. Destaco, porém, que a camiseta listrada de vermelho e branco do protagonista, tem uma ambivalência perigosa. Ela pode remeter, no nosso imaginário, à ideia que temos de um pijama, mas lembra também o padrão de uniformes de presidiários. Assim, uma leitura precipitada da capa, onde o protagonista aparece em primeiro plano, pode produzir sentidos opostos aos inicialmente esperados. Importa lembrar a esperteza do menino da narrativa, que tem origem provavelmente no século X e foi recolhida pela primeira vez por Charles Perrault. Numa das ilustrações da versão aqui apresentada, o menino está sobre um amontoado de moedas, representando a cena na qual ele, ao invés de colaborar com os ladrões, está defendendo a venda que está sendo assaltada. Mas antes que se chegue a essa conclusão, o leitor pode, induzido pela imagem da capa, considerar que o menino é o ladrão.

A terceira narrativa é O pequeno príncipe das ruas (2018), de Allex Miranda, publicada pela Editora Uirapuru, com ilustrações de André Vieira. Esse é, para mim, o livro que mais questões apresenta, se comparado com os dois anteriormente mencionados. O texto conta a história de "um homem de negócios, negro bem-sucedido", que vive "no Nordeste brasileiro" (MIRANDA, 2018 , p. 3). Ele acorda atrasado para uma reunião em sua empresa, lembra-se que havia comprometido a ajudar o filho num trabalho escolar, mas parte sem cumprir o prometido. Para encurtar caminho, sai de sua rota habitual e vai atravessar várias cidades em ruínas. O carro estraga; ele tenta pedir ajuda, mas o celular não funciona. Sem saber de onde vem, aparece na frente dele "uma criança negra" (MIRANDA, 2018, p. 4), que vem lhe pedir ajuda para encontrar seu cão, mas o homem se antecipa supondo que fosse pedir dinheiro. Tira do bolso três moedas, dá ao garoto e o manda embora, mas a criança não vai e eles travam uma longa conversa inspirada em elementos da narrativa de O pequeno Príncipe, de Saint Éxupery. Na tentativa de se livrar da criança, ele desenha para ela o cão, com a intenção de se isentar da responsabilidade de procurar com o menino o amigo perdido. Ao ver a imagem, o menino zomba dele porque, ao invés de um cachorro, enxerga no desenho uma ovelha. Eles vão atravessando aquela terra arrasada e se encontram com várias personagens: Obama, o protetor das florestas; a Mãe de Ouro, protetora das riquezas e o cão do menino, que é na verdade o Saci-Pererê. Ao se deparar com essa última 
personagem, o homem descobre que está no mundo imaginário do folclore, do qual havia se esquecido e no qual havia deixado de acreditar, em razão dos caminhos que escolheu e o levaram a ser um homem de negócios. No fim das contas, o homem estava sonhando e, ao acordar, lembra que era 22 de agosto, dia do folclore brasileiro. Ele havia combinado com o filho de ajudálo a fazer um trabalho de escola sobre o tema. No café da manhã, apresenta ao menino um livro cuja ilustração vemos sobre a mesa: é um exemplar de O Pinóquio do asfalto, da mesma coleção da editora Uirapuru.

São muitas as questões suscitadas nessa narrativa. A primeira delas está no título que recupera um clássico da literatura infantil e juvenil francesa, agora protagonizada por um garoto negro; aliás todas as personagens são negras. Até aí tudo bem. Contudo, o título induz a pensar que se trata de uma criança em situação de rua e, na capa, a expressão "das ruas" está em caixa alta ocupando quase que a largura da página, funcionando como subtítulo encimado pelo título em letras menores, deixando claro o destaque que se quer dar à última parte desse título. $\mathrm{O}$ cenário é o "Nordeste brasileiro", termo complicado por ser comum a nós brasileiros o utilizarmos não pensando numa região com nove estados, mas como uma unidade em que dizer ir para o Nordeste não significa ir para Alagoas, Bahia, Sergipe, entre outros, mas para uma região homogênea, de cultura unitária, assim como é comum tratar a África como um país e não como um continente, num procedimento de "valoração social, quase sempre negativa". De acordo com Mateus Servilha, "[e]spaços, em diferentes escalas, ao serem integrados, são objeto de classificações, estigmatizações, esteriotipizações, em meio aos processos de sua produção e controle geográficos (SERVILHA, 2019, p. 40 e 42).

Na sequência, temos a seguinte construção frasal: “[...] um homem de negócios, negro bem-sucedido [...]" (MIRANDA, 2018, p. 3). Como na narrativa todas as personagens são negras, não me pareceu necessário usar o adjetivo negro, a não ser para destacar a pouca frequência com que se vê uma pessoa negra bem-sucedida. As cidades por onde ele passa estão todas em ruínas, fazendo pensar nesse Nordeste brasileiro como pobre, atrasado e, claro, por serem as personagens negras, viverem todas em situação de pobreza, com exceção do homem de negócios. Quando o carro estraga, a tendência é supor que será assaltado ou que a polícia vai confundi-lo com um ladrão. Felizmente a história segue outro rumo, mas não compreendi qual o motivo de tratar do folclore brasileiro tendo como pano de fundo uma narrativa de origem francesa. 
Claro que é no folclore brasileiro que vamos encontrar muitas contribuições culturais de origem africana, mas o Curupira, representado por Obama, e o Saci-Pererê são lendas do repertório indígena. A primeira está relacionada à nação Naua do Acre; a segunda tem origem nos povos indígenas do sul do país, na região conhecida por Missões. Num livro que pretende tratar das relações étnico-raciais, com foco nas culturas afro-brasileiras, é estranho o silenciamento de lendas trazidas por povos de diferentes origens do continente africano, a despeito de, na ficha catalográfica, constar a seguinte informação: "1. Literatura. 2. Cultura Afrobrasileira. 3. Folclore” (MIRANDA, 2018, p. 2).

Se, como diz Tolentino, “[...] o racismo contido em obras da literatura infantil têm sido um instrumento eficaz para demolir a autoestima das crianças negras" (TOLENTINO, 2020, s. p.), algumas produções recentes parecem praticar o racismo cultural, e advogado pela permanência de visões estereotipadas das culturas e povos contemplados pela lei, a qual determina em seu parágrafo primeiro que o conteúdo programático das disciplinas escolares “incluirá o estudo da História da África e dos Africanos, a luta dos negros no Brasil, a cultura negra brasileira e o negro na formação da sociedade nacional, resgatando a contribuição do povo negro nas áreas social, econômica e política pertinentes à História do Brasil” (BRASIL, 2003, p. 1). Refletindo por essa ótica, creio que essas produções dão nova tintura à ideia de democracia racial, reacomodando-a num texto que pouco ou em quase nada atende ao que parecia ter sido formalizado pelo marco legal.

Não devo esquecer, contudo, que essa é apenas uma perspectiva, tendo em vista que há produções seguindo direções contrárias, considerando práticas culturais aportadas no Brasil com a chegada dos africanos, e também o diversificado conjunto cultural oriundo daquele continente. Farei, portanto, uma apresentação de três livros produzidos por Reginaldo Prandi, ilustrados por Pedro Rafael e editados pela Cia das Letrinhas. São eles Ifá, o adivinho (2002), Xangô, o Trovão (2003) e Oxumaré, o Arco-Íris (2004). Destaco que o primeiro veio a público antes da promulgação da Lei e circula em sua segunda edição e quinta reimpressão. O segundo está na sexta reimpressão e o terceiro na quarta. Todos eles, em sua ficha técnica, indicam o folclore como primeira temática. Na folha de rosto de todos há a seguinte informação: "História dos deuses africanos que vieram para o Brasil com os escravos”. Gostaria, porém, de destacar o uso inadequado do termo "escravos", cujo sentido naturaliza uma condição que não o é. 
Em Ifá, o leitor encontra 11 histórias e ao final um glossário com os nomes e breve comentário sobre os 20 Orixás que participam como personagens; o mesmo procedimento se repete nos demais livros, tendo Xangô 10 narrativas e Oxumaré 13. Os três livros têm uma sequência que contribui para que o leitor compreenda a origem das histórias que estão sendo contadas. Ifá inicia com a história d'“O adivinho que escapou da morte”, cujo nome dá título ao livro, e termina com o relato "No final, como os orixás vieram para o Brasil”". No livro Xangô, o texto inicial — "Como as histórias de Xangô chegaram até nós", o autor remete ao livro Ifá como irmão daquele que apresenta, deixando claro para o leitor que são muitas as histórias a serem contadas e finaliza com a narrativa "Como as histórias de Xangô chegaram até nós”. Em Oxumaré, a narrativa inicial — "O dia em que o Arco-Íris estancou a chuva" — já está ambientada no Brasil; a frase de abertura situa o leitor no espaço e no tempo: "Quando havia escravidão em nosso país” (PRANDI, 2017, p. 9) e arremata com “O adivinho e as histórias que se repetem”, evidenciando o aspecto cíclico das histórias míticas ali contadas. Reginaldo Prandi se concentrou em contar a história do povo Iorubá, também conhecido como Nagô, o que representa uma ínfima parcela dos diferentes povos que saíram do continente africano para serem aqui no Brasil escravizados e a reinserção de sua cultura na diáspora, como o culto aos orixás e as formas de vivenciá-lo. O modo como essas narrativas são apresentadas lembra a estruturação dos mitos de origem grega, o que poderia levar o leitor a invalidar meu argumento de que essa produção desconstrói o estereótipo enraizado na cultura brasileira e pratica a identidade em política. Convém, por isso, lembrar que a mitologia grega bebe em outras fontes, como a egípcia, país africano que irradiou práticas culturais para o Ocidente. Posso dizer, por fim, que o autor desses livros encontra uma exterioridade a partir da qual dá ao leitor a oportunidade de conhecer um pouco a história dos afro-brasileiros e sua relação direta com uma ancestralidade que resiste nos Terreiros de Candomblé, no culto aos Orixás, no jogo de búzios, práticas ainda hoje marginalizadas no Brasil por não serem de origem cristã, branca, europeia e universal.

\section{Conclusão}

Neste trabalho, minha preocupação foi demonstrar, numa breve incursão pela história da literatura infantil e juvenil brasileira, o acúmulo discursivo de um modo de ver as personagens negras, naturalizando-as numa tipificação estereotipada, ancorada na noção de política de identidade, mas também o movimento seguindo na contramão dessa perspectiva. Vali-me, 
portanto, do termo identidade em política para evidenciar que, contrários à episteme "universalizante", há movimentos pluriversais e de uma exterioridade que visa desnaturalizar e desconstruir os discursos que invisibilizam e silenciam as produções culturais dos africanos e afro-brasileiros, desconsiderando sua importância na constituição das identidades do povo brasileiro.

Para tanto, recuperei no texto de Michel Foucault a noção de episteme e o momento no qual o autor, ao lançar os olhos para a América Latina, o faz percebendo o "encanto exótico de um outro pensamento”. Ainda que a percepção do filósofo francês demonstre um avanço em relação ao pensamento universalizante da episteme ocidental, o olhar de Foucault está vinculado à ideia de exótico, porque a forma de pensar borgiana está fecundada e é produzida fora da episteme ocidental. Acredito ser contra essa perspectiva que argumenta o texto de Walter Mignolo, cujo texto é um convite à prática da desobediência epistêmica, tendo sido esse meu intento ao apresentar aqui algumas produções literárias que se instituíram e se instituem na e com a episteme ocidental e aquelas que escolheram praticar a desobediência epistêmica.

A Lei 10.639/2003, depois de quase 20 anos de sua promulgação, subsidiou meu questionamento sobre a forma como o mercado editorial vem atendendo à demanda gerada pela regulamentação que alterou a LDB. Se, por um lado, constatei a reacomodação da ideia de democracia racial, com uma produção ainda com forte carga de estereotipização, por outro, foi possível observar o zelo com que Reginaldo Prandi e Pedro Rafael imergem no estudo das culturas africanas, de modo a fazê-las emergirem sem o exotismo com o qual foram vistas e julgadas ao longo da nossa história. Por fim, convém perguntar se, após 17 anos do marco legal mencionado, a literatura infantil vem cumprindo o papel que a ela foi delegado de ser umas das vozes a dar visibilidade ao que foi silenciado por 500 anos de episteme ocidental. A resposta me parece bastante complexa, dado o curto espaço de tempo desde a edição da lei. Contudo, é possível dizer sim e não ao mesmo tempo, pois há ainda um longo trajeto a ser percorrido e compete a nós, professores, pesquisadores, militantes de movimentos sociais, a nós, brasileiros, a responsabilidade de compreender o passado como uma luz possível para nos guiar na escuridão do presente, rumo a um futuro outro, plural e inclusivo. 


\section{Referências}

ABBAgnAnO, N. Dicionário de filosofia. Trad. Alfredo Bosi. São Paulo: WFM/Martins Fontes, 2012. Episteme. p. 391.

AGOSTINHO, C.; COELHO, R. S. (Adapt.). Chapenżinho vermelho e o boto-cor-de-rosa. Ilustrações de Walter Lara. Belo Horizonte: Mazza Edições, 2020.

Agostinho, C.; COELHO, R. S. (Adapt.). O pequeno Polegar. Ilustrações de Walter Lara. Belo Horizonte: Mazza Edições, 2019.

ALENCAR. J. de. O Tronco do Ipê. In: Obra completa. Afrânio Coutinho (Org.) Rio de Janeiro: José Aguilar, 1958. p. 625-812. (Vol. III).

ANDERSON, B. Nação e Consciência Nacional. Trad. Lólio Lourenço de Oliveira. São Paulo: Ática, 1989.

BAKHTIN, M. Problemas da poética de Dostoiévski. 5. ed. rev. Trad. Paulo Bezerra. Rio de Janeiro: Forense Universitária, 2010.

BASTIDE, R. Estudos afro-brasileiros. São Paulo: Perspectiva, 1972.

BILAC, O.; COELHO, N. Contos Pátrios. Rio de Janeiro: Francisco Alves, 1961.

BRASIL. Lei 10.639/2003. Disponível em: http://etnicoracial.mec.gov.br/images/pdf/lei_10639_09012003.pdf. Acesso em: 29 ago. 2020.

BROOKSHAW. D. Cor e raça na literatura brasileira. Porto Alegre: Mercado Aberto, 1983.

COELHO NETO, H. M. Panorama Histórico da Literatura Infantil e Juvenil. São Paulo: Ática, 1991.

FOUCAULT, M. As palavras e as coisas. Trad. Salma Tannus Muchail. São Paulo: Martins Fontes, 2002.

FRANÇA, L. F. Personagens negras na literatura infantil brasileira: da manutenção à desconstrução do estereótipo. 2006. 167 fls. Dissertação (Mestrado em Estudos de Linguagem) — Universidade Federal do Mato Grosso: Instituto de Linguagens, 2006.

HOUAISS, A.; VILLAR, M. S. Dicionário Honaiss da Lingua Portuguesa. Rio de Janeiro: Objetiva, 2009.

LAJOLO, M.; ZILBERMAN, R. Literatura Infantil Brasileira: história e histórias. São Paulo: Ática, 2002.

LAJOLO, M.; ZILBERMAN, R. Um Brasil para crianças: para conhecer a Literatura Infantil Brasileira: histórias, autores e textos. São Paulo: Ática, 1993.

LISBOA, A. A bonequinha preta. Ilustração: Ana Raquel. 3. ed. Belo Horizonte: Editora Lê, 2004.

LOBATO, M. Histórias de Tia Nastácia. São Paulo: Brasiliense, 1995.

MACHADO, A. M. Menina bonita do laço de fita. 9. ed. Ilustrações Claudius. São Paulo: Ática, 2011. (Coleção Barquinho de Papel).

MIGNOLO, W. Desobediência epistêmica: a opção descolonial e o significado de identidade em política. Cadernos de Letras da UFF, língua e identidade, n. 34, p. 287-324, 2008. 
MIRANDA, A. O pequeno príncipe das ruas. Ilustrações André Vieira. São Paulo: Editora Uirapuru, 2018.

PRANDI, R. Ifá, o adivinho. Ilustrações: Pedro Rafael. São Paulo: Cia das Letrinhas, 2017.

PRANDI, R. Oxumaré, o Arco-íris. Ilustrações: Pedro Rafael. São Paulo: Cia das Letrinhas, 2017.

PRANDI, R. Xangô, o trovão. Ilustrações: Pedro Rafael. São Paulo: Cia das Letrinhas, 2003.

PROENÇA FILHO, D. A trajetória do negro na literatura brasileira. Revista de Estudos Avançados, v. 18, n. 50, 2004.

RIBEIRO, D. O que é lugar de fala. Belo Horizonte: Letramento, 2017. (E-book).

SCHWARCZ, L. M. O espetáculo das raças - cientistas, instituições e questão racial no Brasil 1870-1930. São Paulo: Cia das Letras, 1993.

SERVILHA, M. de M. Espaço, estigma e sujeito: reflexões na produção de uma geografia social crítica. Revista da Associação Nacional de Pós-graduação e Pesquisa em Geografia (Anpege), v. 15, n. 26, p. 36-66, jan./mar. 2019.

SOUZA, Z. L. Do discurso político ao discurso literário: o (não) lugar do negro na nação imaginada por José de Alencar. 149 fls. Dissertação (Mestrado em Estudos Literários) — Universidade Estadual de Montes Claros: Programa de Pós-Graduação em Letras / Estudos Literários, Montes Claros, 2015.

TOLENTINO, L. Por uma infância sem racismo, "Chapeuzinho Vermelho e o Boto Cor-de-Rosa". In: Carta Capital. 2020. Disponível em: https://www.cartacapital.com.br/opiniao/por-uma-infancia-semracismo-chapeuzinho-vermelho-e-o-boto-cor-de-rosa/. Acesso em: 29 ago. 2020.

RECEBIDO: 22/02/2021

RECEIVED: 02/22/2021

APROVADO: 10/07/2021

APPROVED: 07/10/2021 